\title{
Juvenile hawksbill residency and habitat use within a Caribbean marine protected area
}

\author{
Thomas H. Selby ${ }^{1, *}$, Kristen M. Hart' ${ }^{2}$, Brian J. Smith ${ }^{1}$, Clayton G. Pollock ${ }^{3}$, \\ Zandy Hillis-Starr ${ }^{3}$, Madan K. Oli ${ }^{4}$ \\ ${ }^{1}$ Cherokee Nation Technologies, Contracted to the U.S. Geological Survey, Davie, Florida 33314, USA \\ ${ }^{2}$ U.S. Geological Survey, Wetland and Aquatic Research Center, Davie, Florida 33314, USA \\ ${ }^{3}$ National Park Service, Buck Island Reef National Monument, Christiansted, St. Croix, US Virgin Islands 008020-4611, USA \\ ${ }^{4}$ Department of Wildlife Ecology and Conservation, University of Florida, Gainesville, Florida 32611-0430, USA
}

\begin{abstract}
Understanding the spatial ecology of highly mobile marine vertebrates is necessary for informing conservation and management strategies aimed at protecting such species. Buck Island Reef National Monument (BIRNM), off the coast of St. Croix, US Virgin Islands, harbors critical foraging habitat for Critically Endangered juvenile hawksbills Eretmochelys imbricata that exhibit high site fidelity until sexual maturation. Using an array of fixed passive acoustic receivers that covered over $20.2 \mathrm{~km}^{2}$ at its largest configuration and in-water biannual sampling, we analyzed residency patterns and habitat use of 29 hawksbills. High recapture rates allowed for longterm data collection for some individuals, with 1 individual being detected within the array $1952 \mathrm{~d}$ (mean \pm SD: $411 \pm 444 \mathrm{~d}$ ). We used detection data to construct a resource selection function based on a generalized linear mixed model in order to determine relative habitat selection, or the use of different habitat types within an area proportional to the 'true' selection. Our covariates in the model were benthic structure, bathymetry, time of day, and year. Results showed selection by tagged individuals for shallow $(<20 \mathrm{~m})$ depths in areas with high rugosity characterized by a high density of reef or rock. However, individuals also selected areas comprised primarily of sand interspersed with seagrass pastures. We also used the best supported model to predict relative selection across BIRNM and found that the total area of high relative selection decreased significantly at night. The information provided will help guide both future in-water surveys for cryptic hawksbills and management decisions about public area-use at BIRNM.
\end{abstract}

KEY WORDS: Passive acoustic telemetry $\cdot$ Eretmochelys imbricata $\cdot$ Resource selection function • Residency

\section{INTRODUCTION}

Coastal marine ecosystems across the globe are threatened by direct and indirect anthropogenic influences (Halpern et al. 2015). Similar to terrestrial reserves, marine protected areas (MPAs) have become a popular conservation tool to mitigate detrimental influences within designated areas (Keller et al. 2009). Designation and management of MPAs often takes into consideration large, charismatic mar-

${ }^{*}$ Corresponding author: thomas.h.selby@gmail.com ine vertebrates despite the inherent difficulties of protecting such species using place-based management methods (Browman et al. 2005, Keller et al. 2009). One argument for this is the recognition that marine megafauna can have important influences on coastal ecosystem communities, typically through top-down processes (Heithaus 2013, Hays et al. 2016). Understanding how and the extent to which such species use a protected area (including preference for areas outside of an MPA) can help better

(C) The authors 2019. Open Access under Creative Commons by Attribution Licence. Use, distribution and reproduction are unrestricted. Authors and original publication must be credited. 
inform management decisions as well as provide insight into the state of other protected resources.

Distributed globally throughout the tropics, hawksbill sea turtles Eretmochelys imbricata are one such species of marine megafauna shown to directly impact coral reef ecosystems through their consumption of macroalgae and sponges (Meylan 1988, León \& Bjorndal 2002, Gaos et al. 2012, Bell 2013). However, habitat degradation, direct take, and incidental bycatch over the past century have greatly reduced global hawksbill populations, causing the IUCN to list the species as Critically Endangered (Mortimer \& Donnelly 2008). Similar to other marine turtle species, hawksbills exhibit ontogenetic shifts over long lifespans wherein they use both pelagic and coastal environments (Musick \& Limpus 1997, Godley et al. 2008). Post-hatchling hawksbills spend a variable number of years foraging at or near the surface in drifting oceanic weed lines during the 'lost years' before actively recruiting to neritic habitats and switching to a demersal foraging behavior (Musick \& Limpus 1997). Juveniles remain resident in these developmental foraging areas until sexual maturation (between 10 and 20 yr of age), after which they typically exhibit more migratory behavior between mating, nesting (for females), and foraging grounds. The transitory nature across relatively large and often remote areas makes place-based protection for posthatchling and adult hawksbills unrealistic. In contrast, the juvenile developmental stage offers a practical opportunity to protect hawksbills using MPAs.

Designing and effectively managing MPAs for hawksbills requires knowledge about their spatial ecology. A variety of techniques have been used to investigate the spatial ecology of juvenile hawksbills within the Caribbean region. Several studies using in-water capture-mark-recapture (CMR) have provided important information on the population demographics, residency time, and horizontal displacement between capture events of juvenile hawksbills (van Dam \& Diez 1998, Blumenthal et al. 2009a, Hart et al. 2013, Strindberg et al. 2016). Active tracking, whereby a tagged individual is followed from a boat using a directional receiver, produced preliminary estimates of home range, whereas time-depth recorders provided data on diurnal dive patterns (van Dam \& Diez 1997, 1998, Blumenthal et al. 2009b, Witt et al. 2010, Scales et al. 2011, Berube et al. 2012, Wood et al. 2017). Results from these studies indicate long-term residency patterns of juvenile hawksbills within coastal Caribbean habitats. However, most previous studies had small sample sizes (<10 individuals), short tracking durations
( $<25$ d), limited spatial data ( $<20$ unique locations), or some combination of these. Passive acoustic telemetry is increasingly being used to track larger numbers of individuals while mitigating some of the problems outlined above inherent to these other techniques.

Fixed passive acoustic telemetry provides continuous, fine-scale location data for numerous individuals over extended periods of time (years) with less potential for influencing animal behavior compared to active tracking (Heupel et al. 2006, Kessel et al. 2014, Hussey et al. 2015, Zeh et al. 2015). Fixed passive acoustic technology combines the portable hydrophone and receiver used for active acoustic tracking into a single submersible unit referred to simply as a receiver. Receivers anchored to the substrate at predetermined locations record the date, time, and tag ID (collectively termed a detection) of any acoustic tag within the receiver's range. The technology is used extensively to understand the movement of numerous fish species, but only recently has it been used to examine marine turtle spatial ecology (Hazel et al. 2013, Chevis et al. 2017).

The array at Buck Island Reef National Monument (BIRNM), US Virgin Islands, is unique in both its coverage and longevity and was made possible through the continued collaboration of academic and government (both local and federal) researchers. These factors provided us the opportunity to quantify previously suggested behavior patterns of juvenile hawksbills and establish a baseline for future comparisons. Higher-resolution spatial and temporal habitat-use data provide more power to detect anomalous changes in the environment through shifts in behavior. This is especially important in the highly connected and dynamic marine environment, where adverse anthropogenic threats far from an MPA boundary, such as an oil spill, or regionally imposed threats, such as climate change, can have detrimental effects on those areas protected by the MPA over time.

Using this fixed passive acoustic array of receivers, we investigated the residency and habitat-use trends of juvenile hawksbills captured within the protected waters of BIRNM. Specifically, our objectives were to (1) examine residency through temporal detection patterns of tagged hawksbills within the array, and (2) investigate space use within BIRNM using a resource selection function (RSF) framework to understand relative selection based on 4 covariates: benthic substrate, bathymetry, time of day, and year. Results from our study will give resource managers insight into areas of potential importance for juvenile hawksbills at BIRNM. 


\section{MATERIALS AND METHODS}

\subsection{Study site}

Designated in 1961, BIRNM originally encompassed $3.6 \mathrm{~km}^{2}$, including the uninhabited Buck Island, until the boundary was expanded in 2001 to $73.4 \mathrm{~km}^{2}$. Managed by the US National Park Service, BIRNM is one of only a few no-take marine protected areas in the Caribbean and harbors a diverse assortment of habitats (Guarderas et al. 2008). An emergent reef crest surrounds Buck Island, creating a shallow 50$150 \mathrm{~m}$ wide lagoon starting on the southern side and continuing counterclockwise to the northwest corner, where it breaks apart into a series of isolated patch reefs. South/southwest of Buck Island are sea grass beds comprised of Syringodium sp., Thalassia sp., and Halophila sp. interspersed with low-rugosity sand. North of Buck Island are densely clustered remnant stands of dead elkhorn coral Acropora palmata that rise to the surface from a depth of 9-15 $\mathrm{m}$, called 'haystacks' (Bythell et al. 1989). The receiver locations were centralized around Buck Island and dispersed throughout the various habitats (Fig. 1). The passive acoustic array at BIRNM began as 6 Vemco VR2W receivers (Vemco Amirix Systems) deployed in September 2011 and through subsequent collaborations reached 141 receivers at its pinnacle. Receiver downloads and station maintenance were performed twice a year.

\subsection{Field sampling}

We began capturing and tagging juvenile hawksbills in the spring of 2012. Subsequent tagging trips lasted between 8 and $10 \mathrm{~d}$ and were conducted twice annually (spring and fall) until 2016. To capture individuals, 2 teams of 3 snorkelers swam designated transects and pursued any observed hawksbills from the surface until they settled on the sea floor. One team member would then free-dive to the bottom and grasp the turtle firmly by the carapace at the nuchal and anterior marginal scutes before slowly
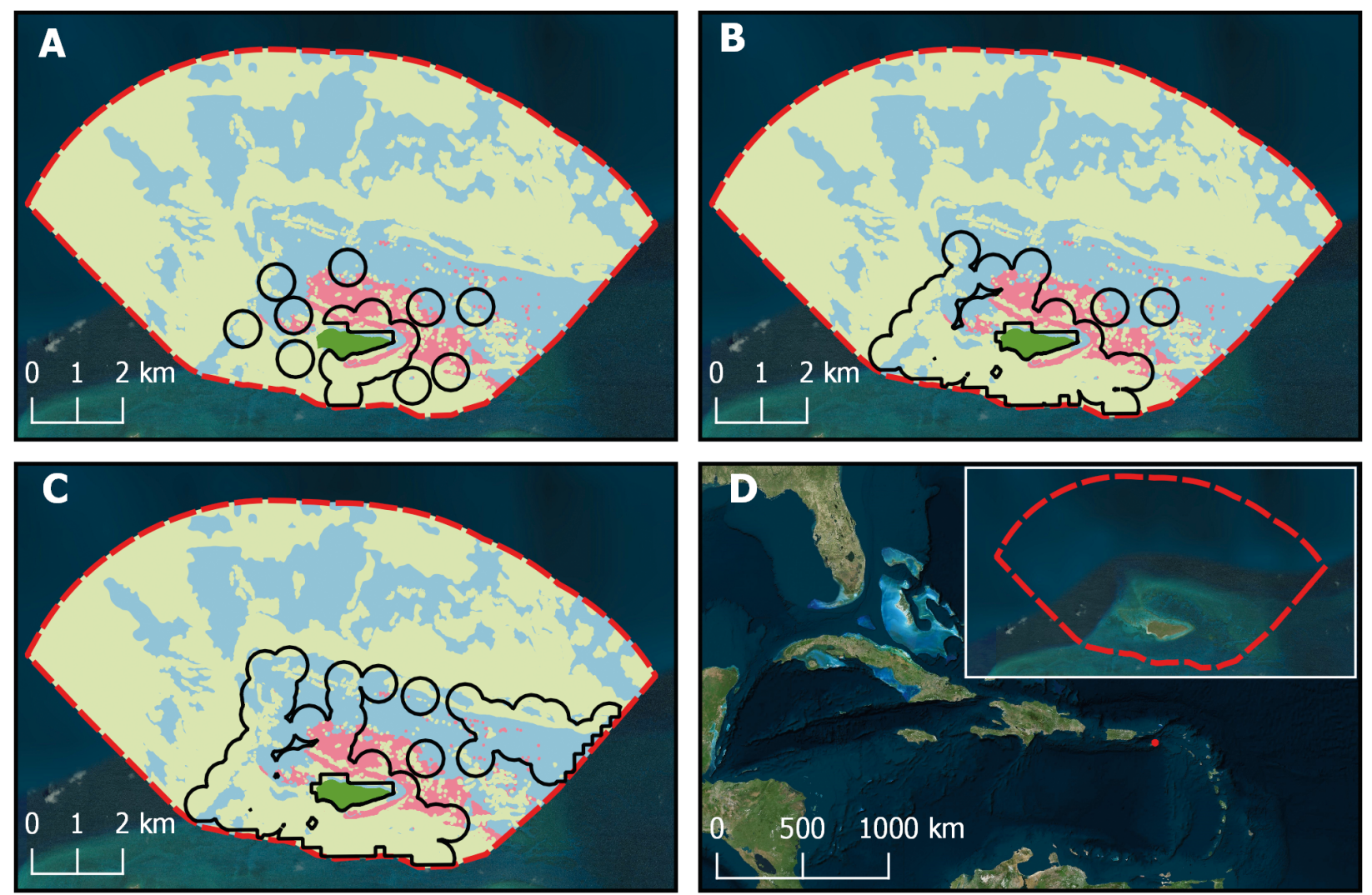

Fig. 1. Buck Island Reef National Monument (BIRNM) passive acoustic receiver array coverage, showing the 3 benthic structures: high-rugosity reef (pink), low-rugosity sand (green), and low-rugosity hardbottom (blue). The dashed red line represents the BIRNM boundary; dark green shows Buck Island. Available habitat is outlined in black based on the $400 \mathrm{~m}$ buffer applied to the receivers comprising the array. Available habitat based on array size in (A) 2012, (B) 2013-2015, and (C) 2016-2017. (D) Relative location of BIRNM within the greater Caribbean region 
ascending with the turtle's head pointed towards the surface. We recorded morphometric measurements before tagging individuals with either Vemco V16-4L $(16 \times 88 \mathrm{~mm}, 24 \mathrm{~g}$ in air, $69 \mathrm{kHz}, 152 \mathrm{~dB}$, with 30-90 s delay interval) or V13-1L $(13 \times 36 \mathrm{~mm}, 11 \mathrm{~g}$ in air, 60$84 \mathrm{kHz}, 147 \mathrm{~dB}$, with 30-90 s delay interval) acoustic tags depending on the individual's size; no tag exceeded $0.8 \%$ of an individual's body weight in air. We attached acoustic tags to the flattest section of posterior marginal scutes using rubber-coated wire and Devcon Marine Plastic Putty with the transmitting end left open so as not to interfere with signal transmission. All turtles were released within $1 \mathrm{~h}$ at the point of capture.

\subsection{Data analysis}

\subsubsection{Data filtering}

False positive detections, more commonly referred to simply as false detections, occur when tag transmissions are distorted by other nearby acoustic signals with similar frequencies (Simpfendorfer et al. 2015). Some false detections appear as new unknown tag IDs, which are easily filtered and removed. More problematic are type B false detections, which record as a known deployed transmitter that was not in actual proximity of the receiver (Simpfendorfer et al. 2015). We flagged potential type B false detections using 2 filters created in R version 3.4.3 (R Core Team 2017). The first basic filter flagged any detections that occurred before a tag was deployed or after the estimated battery life provided by the tag manufacturer (2808 d for V16s and $623 \mathrm{~d}$ for V13s). The second filter flagged any detections that indicated an unrealistic swim speed for juvenile hawksbills $\left(>10 \mathrm{~m} \mathrm{~s}^{-1}\right.$ ) between receivers more than $1 \mathrm{~km}$ apart (Revelles et al. 2007, MacDonald et al. 2013). Distances between receivers were calculated using a least cost pathways analysis in R with raster data of BIRNM's major habitat types and bathymetry. Land (Buck Island) and shallow $(<1 \mathrm{~m})$ reef were scored as highly resistant so that the resulting distance matrix between receivers reflected the shortest distance between receivers that a hawksbill could potentially swim (Zeller et al. 2012).

\subsubsection{Residency}

To investigate individual detection history within the array, we created a residency plot visually depicting when an individual was detected in the array over time. We also calculated a residency index $\left(I_{R}\right)$ for each individual by dividing the total number of days detected in the array since initial tag deployment by 365 d (Abecasis \& Erzini 2008, O'Toole et al. 2011). We chose 365 d from initial tag deployment to calculate $I_{R}$ because it gave us a year of detection history and was the maximum number of days between the last acoustic tag deployment and the latest array download. An $I_{R}=1$ indicates that an individual was detected within the array at least once every day for the $365 \mathrm{~d}$ period, whereas an $I_{R}=0$ implies that an individual was never detected within the array.

\subsubsection{RSF model}

RSF models are a type of point process model that compare spatial locations with randomly assigned background points within a predetermined available area for tagged individuals (Boyce \& McDonald 1999). By definition, RSFs are proportional to the true probability of selection; therefore, selection strengths are considered relative to each other and not in absolute terms (Manly 2002). Thus, throughout this paper, we will refer to the quantities estimated by our RSF as 'relative selection.' The resulting binary data structure can be analyzed using a generalized linear mixed model (GLMM) with a binomial distribution where individuals' locations are coded as ' 1 ' and the random available points as ' 0 ' (Hebblewhite \& Merrill 2008). Covariates associated with those locations are evaluated to determine relative selection for each habitat, with individual included as a random effect to account for individual variability and unequal sampling.

After filtering out type B false detections using the methods described above, we calculated centers of activity (COAs) for tagged individuals based on the mean position algorithm (Simpfendorfer et al. 2002). The mean position algorithm calculates a COA for an individual by taking the average of the receiver locations where detections occurred within a certain time interval, $\Delta t$ (Worton 1987, Simpfendorfer et al. 2002). We chose a $\Delta t$ of $60 \mathrm{~min}$ to reduce temporal autocorrelation between locations, but also to maintain as fine-scale temporal resolution as possible (Scales et al. 2011, Chevis et al. 2017). Individuals with $\leq 100$ COAs were removed from the data, leaving 24 individuals for analysis.

Critical to implementing an RSF model, especially with highly mobile species, is defining a meaningful scale for available habitat (Hooten et al. 2017). This is further complicated in the case of passive acoustic 
technology, where location information is inherently inferred from static receivers with dynamic ranges (Selby et al. 2016). We must therefore restrict our inference to areas covered by the array. Based on previous range-testing of the array at BIRNM, we chose a $400 \mathrm{~m}$ buffer around each receiver to represent our 'available' habitat and removed any COAs outside of the buffer region (Selby et al. 2016). We chose bathymetry, benthic structure, time of day (day 07:00-18:59 h, night 19:00-06:59 h), and year as our covariates. Benthic structure was categorized based on rugosity and structure type as either high-rugosity relief, low-rugosity sand, or low-rugosity hardbottom. High-rugosity relief was characterized by dense, highly rugose physical benthic structure such as reef and rock. Low-rugosity sand comprised homogenous sand interspersed with sea grass pastures, and lowrugosity hardbottom contained low-lying rock interspersed with occasional relief and soft corals. To account for location error associated with COAs, we resampled the benthic structure and bathymetry rasters to a coarser $200 \times 200 \mathrm{~m}$ resolution. We recalculated the benthic structure raster using the mode of adjacent cell values and used the nearest neighbor technique to recalculate the bathymetry. Year was included as a covariate to account for array expansion. We randomly generated locations restricted to the available habitat where the number of random points equaled the number of $\mathrm{COA}$ locations for each individual. This established a null probability of selection of 0.5 for detecting active selection of a habitat type in comparison to random selection.

We fit a GLMM with a logit link function and a binomial error distribution where our response variable was observed (individual location data $=1$ ) or not observed (randomized point within available area $=0$ ) using the package 'Ime4' in RStudio with $\mathrm{R}$ version 3.4.3 (Bates et al. 2015, R Core Team 2017). Individual turtle identity was included as the random effect to account for variability among individuals and unequal sampling. We scaled and centered our continuous variables bathymetry and year to help achieve model convergence. Model selection was done using Akaike's information criterion corrected for finite samples sizes ( $\mathrm{AICc}_{\text {; }}$ Burnham \& Anderson 2002). We visualized hawksbill habitat selection throughout BIRNM by using coefficients from the best-supported model to predict relative habitat selection at the population level using the combined raster layers and holding the other covariates constant.

\section{RESULTS}

\subsection{Residency}

Between March 2012 and March 2017, we captured and tagged 29 hawksbills with an acoustic transmitter (Table 1). Size of individuals at the time of their initial tagging ranged from 22.0 to $85.5 \mathrm{~cm}$

Table 1. Residency intervals $\left(I_{R}\right)$ and detection history for each juvenile hawksbill turtle tagged at Buck Island Reef National Monument. Detection data are based on post filtering results. $I_{R}$ was calculated by dividing the total number of days detected in the array since initial tag deployment by $365 \mathrm{~d}$. CCL: curved carapace length. Dates are given as yr-mo-d

\begin{tabular}{|c|c|c|c|c|c|c|c|}
\hline $\begin{array}{l}\text { Turtle } \\
\text { ID }\end{array}$ & $\begin{array}{l}\text { Initial tag } \\
\text { date }\end{array}$ & $\begin{array}{l}\text { Last date } \\
\text { detected }\end{array}$ & $\begin{array}{l}\text { CCL } \\
(\mathrm{cm})\end{array}$ & $\begin{array}{c}\text { Days } \\
\text { detected } \\
\text { (n) }\end{array}$ & $I_{R}$ & $\begin{array}{c}\text { Total } \\
\text { detections } \\
\text { (n) }\end{array}$ & $\begin{array}{l}\text { Total } \\
\text { receivers } \\
\text { (n) }\end{array}$ \\
\hline A1 & 2012-03-13 & $2015-11-28$ & 48.8 & 827 & 0.69 & 47453 & 20 \\
\hline A2 & 2012-03-14 & 2013-03-09 & 51.8 & 262 & 0.72 & 5723 & 12 \\
\hline A3 & 2012-03-18 & 2017-09-06 & 51.4 & 1952 & 0.96 & 305085 & 50 \\
\hline A4 & 2012-03-19 & 2012-06-25 & 53.5 & 96 & 0.26 & 26446 & 9 \\
\hline A5 & 2012-03-20 & 2016-10-18 & 40.9 & 433 & 0.37 & 7361 & 57 \\
\hline B1 & 2012-04-11 & 2012-10-03 & 60.9 & 94 & 0.26 & 1775 & 8 \\
\hline B2 & 2012-04-11 & 2017-10-29 & 39.6 & 1518 & 0.72 & 117877 & 52 \\
\hline B3 & 2012-04-11 & 2016-07-16 & 32.2 & 873 & 0.50 & 180840 & 24 \\
\hline B4 & 2012-04-12 & 2014-03-14 & 55.4 & 549 & 0.86 & 9435 & 10 \\
\hline B5 & 2012-04-12 & 2014-01-01 & 64.4 & 544 & 0.91 & 50429 & 15 \\
\hline B6 & 2012-04-13 & $2012-12-11$ & 56.0 & 169 & 0.46 & 2098 & 12 \\
\hline $\mathrm{C} 1$ & 2012-09-14 & 2014-02-15 & 39.2 & 4 & 0.00 & 9 & 2 \\
\hline $\mathrm{C} 2$ & 2012-09-14 & 2014-05-19 & 35.0 & 526 & 0.94 & 33597 & 12 \\
\hline C3 & 2012-09-14 & 2012-10-03 & 85.5 & 11 & 0.03 & 94 & 2 \\
\hline $\mathrm{C} 4$ & 2012-09-15 & 2014-06-09 & 40.8 & 114 & 0.25 & 2016 & 6 \\
\hline C5 & 2012-09-16 & 2014-06-10 & 42.0 & 381 & 0.68 & 2326 & 7 \\
\hline C6 & 2012-09-16 & 2014-02-22 & 47.3 & 414 & 0.81 & 7157 & 18 \\
\hline D1 & 2013-04-11 & 2014-05-15 & 40.0 & 201 & 0.51 & 3214 & 11 \\
\hline E1 & 2013-09-06 & 2015-05-01 & 32.0 & 599 & 0.99 & 60627 & 13 \\
\hline $\mathrm{E} 2$ & 2013-09-07 & $2016-10-20$ & 29.8 & 471 & 0.52 & 30820 & 21 \\
\hline F1 & 2014-02-25 & 2014-03-10 & 32.8 & 1 & 0.00 & 1 & 1 \\
\hline $\mathrm{F} 2$ & $2014-02-27$ & 2015-10-04 & 35.4 & 149 & 0.20 & 2493 & 8 \\
\hline F3 & 2014-02-27 & 2017-05-16 & 37.7 & 482 & 0.48 & 24787 & 38 \\
\hline $\mathrm{F} 4$ & 2014-03-02 & 2014-10-06 & 37.2 & 3 & 0.01 & 10 & 1 \\
\hline F5 & 2014-03-03 & $2015-10-22$ & 54.5 & 50 & 0.05 & 849 & 10 \\
\hline F6 & 2014-03-05 & $2015-10-23$ & 42.5 & 297 & 0.50 & 3186 & 9 \\
\hline G1 & 2015-03-05 & $2015-04-30$ & 78.0 & 5 & 0.01 & 98 & 9 \\
\hline $\mathrm{G} 2$ & 2015-03-06 & 2015-07-19 & 36.3 & 136 & 0.37 & 8670 & 18 \\
\hline G3 & 2015-03-06 & 2017-06-04 & 22.0 & 757 & 0.96 & 20461 & 41 \\
\hline
\end{tabular}


curved carapace length to the tip (CCL-tip) (mean \pm $\mathrm{SD}=42.5 \pm 10.7 \mathrm{~cm})$, with the majority $(76 \%)$ of individuals $(\mathrm{n}=22)$ between 30 and $60 \mathrm{~cm}$. Acoustic tag retention, based on detection and capture history, ranged from 19 to $1522 \mathrm{~d}$ (mean $=588 \pm 370 \mathrm{~d}$ ), with 13 individuals recaptured at least once on subsequent in-water capture trips. In total, 958767 detections were recorded over the course of the study, of which 694 detections were flagged and removed (588 detections were outside of the battery interval, and 106 violated the speed filter). We observed 2 distinct patterns of detection within the array: frequent and periodic (Fig. 2). Days detected in the array per individual (including tags removed and replaced with a new tag) ranged from 1 to $1952 \mathrm{~d}$ with a mean of $411 \pm 444 \mathrm{~d}$. The mean number of days between first and last transmission was $693 \pm 559 \mathrm{~d}$. Residency indices calculated by dividing the total number of days an individual was detected in the array by 365 ranged from $<0.01$ to $98.0 \%$, with a mean $I_{R}$ of $42.7 \pm 31.7 \%$. Twelve of the 29 tagged individuals had $I_{R}>50.0 \%$, indicating that they were detected by 1 or more receivers in the array at least half of the $365 \mathrm{~d}$ post deployment. Conversely, 5 individuals (C1, F1, F4, F5, and G1; Table 1) had $I_{R} \leq 0.01$. A linear regression showed no significant relationship ( $\mathrm{p}=0.27$ ) between $I_{R}$ and size (CCL-tip).

\subsection{RSF}

We had sufficient detection data (>100 COAs) for 24 tagged individuals for RSF analysis. We compared 4 models using $\mathrm{AICC}_{\mathrm{C}}$ including a null model with only the random effect of individuals included (Table 2). The best-supported model had time of day and year as interactive covariates with quadratic

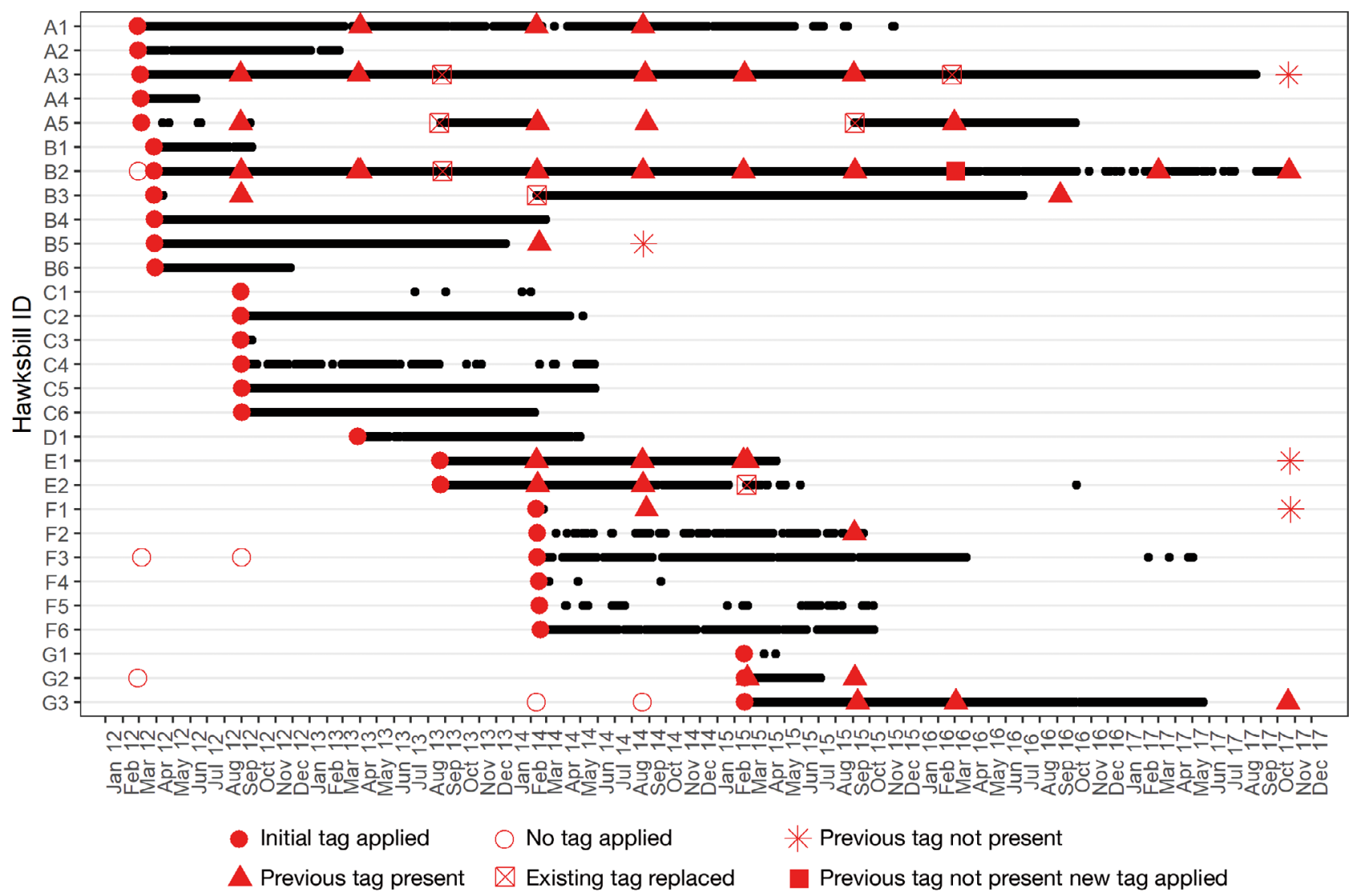

Fig. 2. Residency and capture history for acoustically tagged hawksbill turtles. ( ) Individual was detected within the array on that day. (O) Date on which the initial acoustic tag was attached. (O) Date on which an individual was captured prior to initial tagging. (*) Dates on which an individual was re-captured and a previously attached tag was no longer present, and no new tag was applied. ( $\mathbf{\Delta})$ Individual previously tagged was re-captured and the tag was still present and assumed to be functioning. $(\bowtie)$ Previously tagged individual was recaptured and the existing tag was removed and replaced with another to continue collecting data. ( $\square$ ) A previously tagged individual whose tag fell off prior to that capture date and was replaced 
Table 2. Model structure and rankings with associated corrected Akaike's information criteria (AICc). Model parameters include: bathymetry (Bathy), quadratic bathymetry (Bathy ${ }^{2}$ ), habitat, time of day (Tod), defined as either day (07:00-18:59 h) or night (19:00-06:59 h), and year of the study (Yr). Every model included the tagged individual as an additive random effect

\begin{tabular}{|c|c|c|c|c|}
\hline Model I & Model structure & Parameters & S $\mathrm{AICC}$ & $\triangle \mathrm{AICC}$ \\
\hline M.1 & Bathy $\times$ Tod + Bathy $^{2} \times$ Tod + Habitat $\times$ Tod + Bathy $\times$ Yr + Bathy $^{2} \times$ Yr + Habitat $\times$ Yr & 17 & 155763.8 & 0.0 \\
\hline M.2 & Bathy $\times$ Tod + Bathy $^{2} \times$ Tod + Habitat $\times$ Tod + Yr & 13 & 161893.6 & 6129.8 \\
\hline M.3 & Bathy + Bathy ${ }^{2}+$ Habitat + Tod + Yr & 9 & 163840.7 & 8076.9 \\
\hline M.0 & Null & 2 & 203082.3 & 47318.5 \\
\hline
\end{tabular}

bathymetry and benthic structure. This model had 17 parameters and a model weight of 1 . The $\triangle \mathrm{AICc}$ was 6129.8 between our top model and a slightly reduced model which used only time of day as an interactive covariate, reducing the parameters to 13 . Finally, our most reduced model, which discarded interactive covariates, had only 9 parameters and a $\triangle \mathrm{AICc}$ of 8076.9 .

Using the estimated coefficients from our top model, we examined relative selection in each of the benthic habitats during the day and night as this varied by depth while keeping year constant at 2015. Relative selection was greater for high-rugosity relief and low-rugosity sand during the day, but selection for those habitats decreased at depths $\geq 20 \mathrm{~m}$ (Fig. 3A,B). At night this trend accelerated as depth increased, but there was greater relative selection for lowrugosity sand habitat during the night as opposed to the day (Fig. 3). We found an avoidance of lowrugosity hardbottom structure during both the day and night at any depth (Fig. 3C). Holding bathymetry constant at $5 \mathrm{~m}$ and year at 2015 highlighted the relative selection described for each benthic structure during the day and night (Fig. 4).

The best-supported model was used to predict juvenile hawksbill relative selection across the bathymetry and benthic structure rasters available within BIRNM. Holding year constant at 2015, we predicted relative selection across the monument during the day and night (Fig. 5A,B). The areas adjacent to Buck Island to the south and southwest (which include the shallow south forereef and sand/ seagrass flats) had the highest relative selection by tagged individuals. Relative selection decreased in the deeper depths farther from Buck Island, especially to the north where low-rugosity hardbottom habitat is predominant. This pattern was more pronounced at night, with tagged individuals selecting those shallow high-rugosity relief and low-rugosity sand habitats close to Buck Island (Fig. 5B). The overall area of selected habitat also appears to decrease noticeably at night.

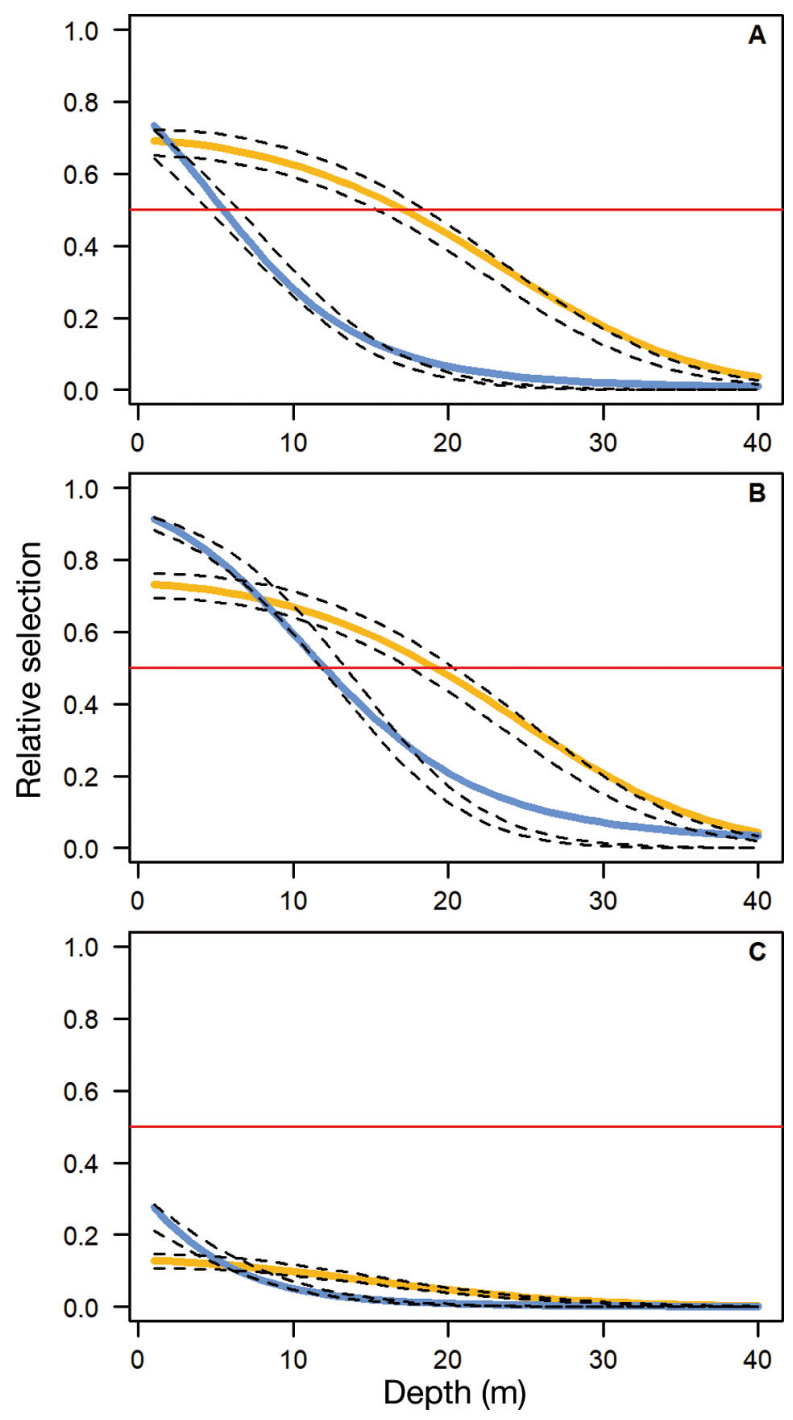

Fig. 3. Relative selection (see Section 2.3.3 for details) by tagged juvenile hawksbill turtles at Buck Island Reef National Monument for the 3 different benthic structure categories with increased depth: (A) high-rugosity reef, (B) lowrugosity sand, (C) low-rugosity hardbottom. Year was held constant at 2015. Relative selection during the day (night) is represented by the yellow (blue) line. The red line indicates that no selection is occurring (i.e. habitat use is in proportion to availability), and the black dashed lines represent the $95 \%$ confidence interval. 


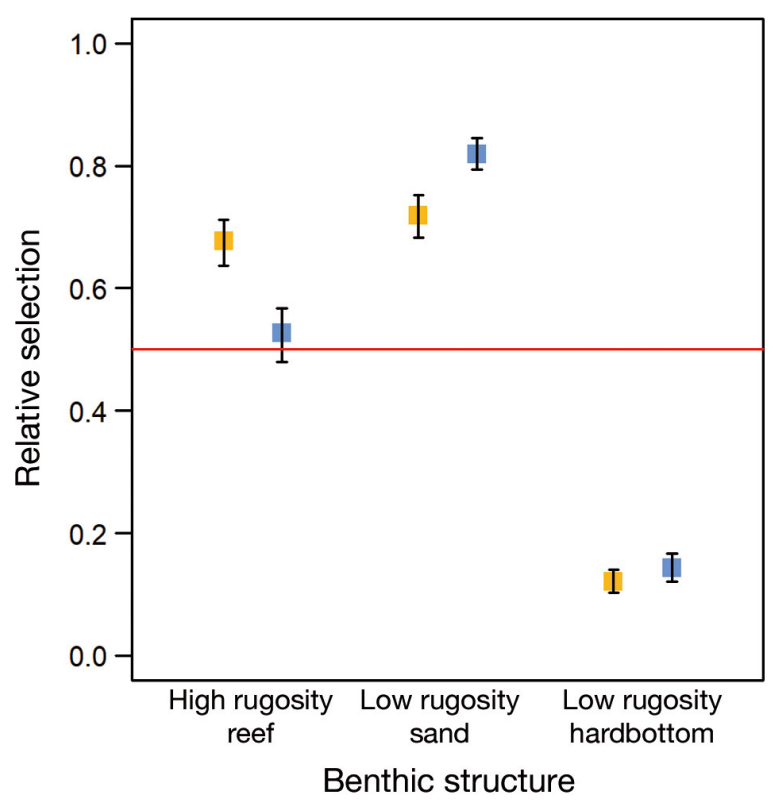

Fig. 4. Relative selection (see Section 2.3.3 for details) by tagged juvenile hawksbill turtles at Buck Island Reef National Monument among 3 benthic structures. The relative selection for high-rugosity reef, low-rugosity sand, and lowrugosity hardbottom is represented for both day (yellow) and night (blue). Depth was held constant at $5 \mathrm{~m}$ and year at 2015. The red line indicates that no selection is occurring (i.e. habitat use is in proportion to availability); error bars show $\mathrm{SD}$

\section{DISCUSSION}

For many highly mobile marine species such as hawksbills, protection from broad scale anthropogenic threats via MPAs can be limited, especially in smaller or less well-regulated MPAs. In contrast, the observed high site fidelity during the post-oceanic juvenile phase presents an opportunity for effective protection using place-based conservation methods and the ability to track changes in protected environments by achieving a quantitative baseline of key species' behavior. Our results help quantify the long-term habitat use by juvenile hawksbills within a coastal Caribbean protected area. Understanding how these individuals use BIRNM is critical to evaluating the efficacy of current management practices, but also provides information for comparison with future cohorts to understand potential shifts in behavior as a result of anthropogenic stressors on the environment there. The RSF analysis provides insight into those habitats/areas of the monument currently being selected for by resident juvenile hawksbills. We expect that this result would generalize well to other coastal areas throughout the Caribbean where juvenile hawksbills are found, and we predict that increased protective efforts (i.e. habitat restoration and law enforcement) in those shallow water, high-rugosity reef and sandy bottom habitats could improve the survival rate of juvenile hawksbill cohorts in the region. Our results improve our knowledge of third-order (i.e. patch-level; Johnson 1980) habitat selection by juvenile hawksbills. More information is still needed at the scale of the specific resources (i.e. fourth-order habitat selection) within each habitat class to better frame the conservation goals within an area where juvenile hawksbills are found. Finally, as the use of passive acoustic technology continues to grow, especially in studies of marine turtles, our results provide a substantive base for controlled comparison with future work as well as insight into the pros and cons of using the technology.

Previous research between 1994 and 1998 at BIRNM using CMR methods determined that residency

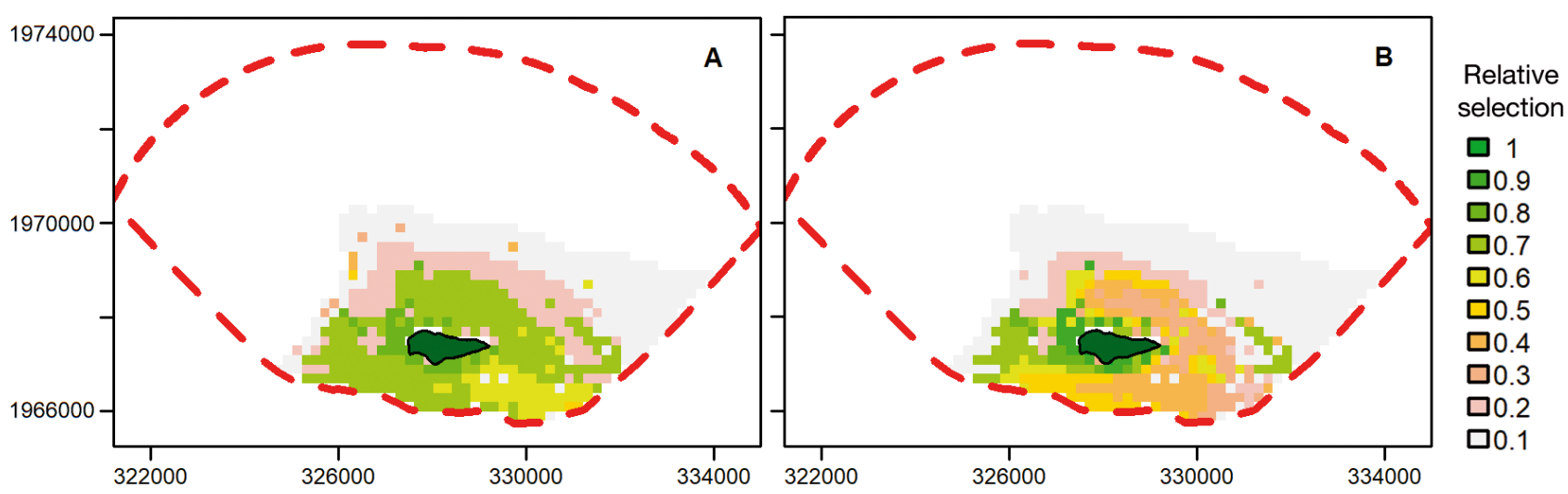

Fig. 5. Predicted relative selection (see Section 2.3.3 for details) by tagged juvenile hawksbill turtles at Buck Island Reef National Monument (A) during the day and (B) at night across the different benthic structure types (high-rugosity reef, lowrugosity sand, low-rugosity hardbottom) and depth. Year was held constant at 2015 for both predictions. Dark green shows Buck Island. UTM coordinates are shown on the $x$ - and $y$-axes for reference 
ranged from 59 to $1396 \mathrm{~d}($ mean $\pm \mathrm{SD}=621 \pm 402 \mathrm{~d}$ ) for 30 hawksbills (including adults) with sufficient recapture data (Hart et al. 2013). These results were consistent with a study by Blumenthal et al. (2009a), another relatively long-term CMR investigation conducted in the Cayman Islands. Using this approach, residency is assumed between capture events. Moreover, the in-water sampling at BIRNM was performed within a limited area primarily to the east/ northeast fringe reef surrounding Buck Island. Passive acoustic technology, in conjunction with inwater sampling, provided continuous long-term data on the residency of tagged individuals within BIRNM between in-water sampling events. Residency profiles from tagged individuals reveal frequent use of areas within the array by at least 10 individuals that, despite intense biannual in-water sampling, were never subsequently recaptured (Fig. 2). Compared to Chevis et al. (2017), who similarly used passive acoustic technology to track 22 juvenile hawksbills at Lighthouse Reef Atoll in Belize, we found a wider range of days detected within the array (1-1952 d [our study] vs. 10-1414 d) and a higher mean number of days between first and last detection $(693 \pm 559 \mathrm{~d}$ [our study] vs. $570 \pm 484 \mathrm{~d}$ ). Our results help to further quantify the notion of site fidelity as it pertains to juvenile hawksbills, showing consistent and longterm use of areas within the array over multiple years by some individuals, but also highlighting the plasticity in habitat use among individuals.

The RSF analysis revealed interesting insights into relative habitat selection by juvenile sea turtles at BIRNM. Previous research has shown that hawksbills primarily associate with coral reefs and other complex hardbottom structures (Cuevas et al. 2007, Blumenthal et al. 2009a, Gaos et al. 2012, Hart et al. 2013). These highly rugose habitats provide an abundance of prey items (sponges and macro algae) as well as protection from large predators (Musick \& Limpus 1997, Blumenthal et al. 2009b). Results from our RSF analysis supported these findings, showing greater relative selection for high-rugosity benthic structure during both the day and night at depths $<20 \mathrm{~m}$. These habitats are clearly important for juvenile hawksbills. Additionally, our results showed selection for low-rugosity sand benthic structure during the day with even greater selection at night at depths $<10 \mathrm{~m}$. This result should be interpreted with caution, as nighttime resting microhabitat is most likely at a finer scale than the $200 \times 200 \mathrm{~m}$ cell size used to distinguish habitat classes. This scale for habitat classification was chosen to match the scale of the data collected within each receiver's effective detection range, and matching the scale of the location data to the scale of the covariates is critical in estimating resource selection (Boyce 2006). In some areas, such as along the south forereef, where receivers fringe both high rugosity reef and low-lying sea grass pastures/sand, the raster cell size may have been too coarse to capture the microhabitat detail. Juvenile hawksbills have been observed using fringe habitats, similar in composition to those encapsulated within our low-rugosity sand and high-rugosity reef categories, to forage for food and rest in the nearby safety provided by the rugose reef structure (Bjorndal \& Bolten 2010, Gorham et al. 2014). Regardless of the particular microhabitat, hawksbills in this study did select these fringe areas at night (Fig. 5B). Increased array coverage in these fringe habitats at BIRNM could help further elucidate microhabitat selection by juvenile hawksbills.

Results from the RSF analysis also showed that the predicted overall area of high relative selection decreased substantially at night. Several studies have suggested that hawksbills use shallow rugose hardbottom structure for resting at night by wedging themselves beneath structure to assist in combating buoyancy and increase dive time (Blumenthal et al. 2009b, Chevis et al. 2017, Wood et al. 2017). Furthermore, Wood et. al. (2017) observed sub-adult individuals using the same 'familiar refuges' at night and found a 'nearly $50 \%$ reduction in the area occupied' at night vs. the day based on kernel density from GPS locations (Wood et al. 2017). Our results suggest a similar behavior by juveniles at BIRNM, and this finding could have potential management implications. First, this resting habitat is presumably crucial to juvenile hawksbills, and without it, the suitability of an area as an MPA for these turtles would be diminished. Second, illegal direct take (i.e. poaching) is a substantial threat even in MPAs, and this highly predictable microhabitat site fidelity could be a behavior that poachers could exploit. Third, identifying these diel patterns informs the study design for ongoing and future surveys of this cryptic species, particularly when it comes to timing surveys when hawksbills are most detectable.

Passive acoustic telemetry, like any technology, has its limitations which are further emphasized when deploying receivers in an open system where entry and exit from the array are not limited by geographic barriers (i.e. rivers, inlets, or bays). Ideally for the RSF analysis, location data and available habitat would be associated with a single receiver or a location determined by triangulation using a VPS system (Freitas et al. 2016). Despite being a rather coarse 
and simplified method for determining individual location data, we feel that the use of COAs and associated location errors are not drastically different from other more classic telemetry methods, especially at the resolution used to define our covariates. Beyond estimating individuals' locations, inherent to any analysis using passive acoustic technology is an effective array design. The array at BIRNM was a collaboration of numerous researchers investigating many different species, from conch to sharks. Thus, the array grew with areas of extensive and sometimes overlapping coverage and other areas with little to no coverage, depending on study-specific objectives. The RSF framework used with passive acoustic telemetry highlights the notion that receivers with no detection data can be as informative as receivers with tens of thousands of detections. Nevertheless, the array coverage for this study was sufficient to provide important insight into the ecology of juvenile hawksbills at BIRNM.

The collaborative effort at BIRNM to build and maintain such a large passive acoustic array highlights some of the advantages and disadvantages of using this technology. Typically, a study on a single species would not have the capability to finance and maintain a passive array of this magnitude for so long. Even if money and time were no issue, GPS tags would provide location data for hawksbills free from fixed locations at a fraction of the cost. However, we consider the necessary collaborative nature of the array at BIRNM a distinct advantage, as it has not only helped to foster species-specific research for multiple key species found in BIRNM, but it has also created the opportunity to look at important interspecific relationships-research which is currently ongoing. Collaborative arrays of this nature are arising around the world, as passive acoustic research shifts from isolated studies to regional networks of arrays (Hussey et al. 2015, Ellis et al. 2019). MPA managers must inevitably determine how to optimally allocate limited funding and effort to protect entire marine ecosystems. Quantifying key species' use of MPA resources provides MPA managers with information in the short-term for analyzing the efficacy of current management practices but also provides a baseline for detecting future changes within the area of interest. Even without high-resolution habitat information, acoustic arrays can yield important information about movement patterns, residency times, and broad scale spatial trends. Collaborative arrays such as the one at BIRNM can provide timely, critical data (absent from other sampling methods) on such species to help inform those decision-making processes.
Acknowledgements. We acknowledge the United States Geological Survey (USGS) Natural Resource Protection Program (NRPP) for funding. We also thank the National Park Service (NPS) and USGS staff and volunteers Mike Cherkiss, Andrew Crowder, Eric Cusin, Scott Eanes, Ian Lundgren, Devon Nemire-Pepe, Lee Richter, Ashley Ruffo, and Kevin Weng, who were critical to the field portion of this study. Finally, we thank Florida Acoustic Cooperative Telemetry (FACT) and United States Caribbean Acoustic Network (USCAN) members for feedback and support. Any use of trade, product, or firm names is for descriptive purposes only and does not imply endorsement by the US Government. Fieldwork was permitted under NMFS permits 16146 and 20315, National Park permits USGS-SESC2014-02 and USGS IACUC WARC \GNV 2017-04, and University of Florida IACUC permit 201408496.

\section{LITERATURE CITED}

Abecasis D, Erzini K (2008) Site fidelity and movements of gilthead sea bream (Sparus aurata) in a coastal lagoon (Ria Formosa, Portugal). Estuar Coast Shelf Sci 79: 758-763

Bates D, Maechler M, Bolker BM, Walker S (2015) Fitting linear mixed-effects models using lme4. J Stat Softw 67: $1-48$

Bell I (2013) Algivory in hawksbill turtles: Eretmochelys imbricata food selection within a foraging area on the Northern Great Barrier Reef. Mar Ecol 34:43-55

* Berube MD, Dunbar SG, Rützler K, Hayes WK (2012) Home range and foraging ecology of juvenile hawksbill sea turtles (Eretmochelys imbricata) on inshore reefs of Honduras. Chelonian Conserv Biol 11:33-43

* Bjorndal KA, Bolten AB (2010) Hawksbill sea turtles in seagrass pastures: success in a peripheral habitat. Mar Biol 157:135-145

Blumenthal J, Austin T, Bell C, Bothwell JB and others (2009a) Ecology of hawksbill turtles, Eretmochelys imbricata, on a western Caribbean foraging ground. Chelonian Conserv Biol 8:1-10

Blumenthal JM, Austin TJ, Bothwell JB, Broderick AC and others (2009b) Diving behavior and movements of juvenile hawksbill turtles Eretmochelys imbricata on a Caribbean coral reef. Coral Reefs 28:55-65

Boyce MS (2006) Scale for resource selection functions. Divers Distrib 12:269-276

* Boyce MS, McDonald LL (1999) Relating populations to habitats using resource selection functions. Trends Ecol Evol 14:268-272

Burnham KP, Anderson DR (2002) Model selection and multimodel inference: a practical information-theoretic approach, $2^{\text {nd }}$ edn. Springer, New York, NY

Bythell JC, Gladfelter EH, Gladfelter WB, French KE, Hillis Z (1989) Buck Island Reef National Monumentchanges in modern reef community structure since 1976. In: Hubard DK (ed) Terrestrial and marine geology of St. Croix, U.S. Virgin Islands. West Indies Lab Spec Publ 8. Fairleigh Dickinson University, St Croix, USVI, p 145-153

Chevis MG, Godley BJ, Lewis JP, Lewis JJ, Scales KL, Graham RT (2017) Movement patterns of juvenile hawksbill turtles Eretmochelys imbricata at a Caribbean coral atoll: long-term tracking using passive acoustic telemetry. Endang Species Res 32:309-319 
Cuevas E, de los Ángeles Liceaga-Correa M, GarduñoAndrade M (2007) Spatial characterization of a foraging area for immature hawksbill turtles (Eretmochelys imbricata) in Yucatan, Mexico. Amphib-Reptil 28: 337-346

Ellis RD, Flaherty-Walia KE, Collins AB, Bickford JW, Boucek R, Walters Burnsed SL, Lowerre-Barbieri SK (2019) Acoustic telemetry array evolution: from speciesand project-specific designs to large-scale, multispecies, cooperative networks. Fish Res 209:186-195

Freitas C, Olsen EM, Knutsen H, Albretsen J, Moland E (2016) Temperature-associated habitat selection in a cold-water marine fish. J Anim Ecol 85:628-637

* Gaos AR, Lewison RL, Wallace BP, Yañez IL and others (2012) Spatial ecology of critically endangered hawksbill turtles Eretmochelys imbricata: implications for management and conservation. Mar Ecol Prog Ser 450:181-194

Godley BJ, Blumenthal JM, Broderick AC, Coyne MS, Godfrey MH, Hawkes LA, Witt MJ (2008) Satellite tracking of sea turtles: Where have we been and where do we go next? Endang Species Res 4:3-22

* Gorham JC, Clark DR, Bresette MJ, Bagley DA and others (2014) Characterization of a subtropical hawksbill sea turtle (Eretmocheyles [sic] imbricata) assemblage utilizing shallow water natural and artificial habitats in the Florida Keys. PLOS ONE 9:1-16

* Guarderas AP, Hacker SD, Lubchenco J (2008) Current status of marine protected areas in Latin America and the Caribbean. Conserv Biol 22:1630-1640

* Halpern BS, Frazier M, Potapenko J, Casey KS and others (2015) Spatial and temporal changes in cumulative human impacts on the world's ocean. Nat Commun 6:7615

Hart KM, Sartain AR, Hillis-Starr ZM, Phillips B and others (2013) Ecology of juvenile hawksbills (Eretmochelys imbricata) at Buck Island Reef National Monument, US Virgin Islands. Mar Biol 160:2567-2580

*Hays GC, Ferreira LC, Sequeira AMM, Meekan MG and others (2016) Key questions in marine megafauna movement ecology. Trends Ecol Evol 31:463-475

* Hazel J, Hamann M, Lawler IR (2013) Home range of immature green turtles tracked at an offshore tropical reef using automated passive acoustic technology. Mar Biol 160:617-627

Hebblewhite M, Merrill E (2008) Modelling wildlife-human relationships for social species with mixed-effects resource selection models. J Appl Ecol 45:834-844

Heithaus M (2013) Predators, prey, and the ecological roles of sea turtles. In: Wyneken J, Lohmann KJ, Musick JA (eds) The biology of sea turtles, Vol III. CRC Marine Biology Series. CRC Press, Boca Raton, FL, p 249-284

Keupel MR, Semmens JM, Hobday AJ (2006) Automated acoustic tracking of aquatic animals: scales, design and deployment of listening station arrays. Mar Freshw Res 57:1-13

Hooten MB, Johnson DS, McClintock BT, Morales JM (2017) Animal movement: statistical models for telemetry data. CRC Press, Boca Raton, FL

KHussey NE, Kessel ST, Aarestrup K, Cooke SJ and others (2015) Aquatic animal telemetry: a panoramic window into the underwater world. Science 348:1255642

Johnson DH (1980) The comparison of usage and availability measurements for evaluating resource preference. Ecology 61:65-71

Keller BD, Gleason DF, McLeod E, Woodley CM and others (2009) Climate change, coral reef ecosystems, and man- agement options for marine protected areas. Environ Manag 44:1069-1088

Kessel ST, Cooke SJ, Heupel MR, Hussey NE, Simpfendorfer CA, Vagle S, Fisk AT (2014) A review of detection range testing in aquatic passive acoustic telemetry studies. Rev Fish Biol Fish 24:199-218

León YM, Bjorndal KA (2002) Selective feeding in the hawksbill turtle, an important predator in coral reef ecosystems. Mar Ecol Prog Ser 245:249-258

*MacDonald BD, Madrak SV, Lewison RL, Seminoff JA, Eguchi T (2013) Fine scale diel movement of the east Pacific green turtle, Chelonia mydas, in a highly urbanized foraging environment. J Exp Mar Biol Ecol 443:56-64

Manly BFJ (2002) Resource selection by animals: statistical design and analysis for field studies. Kluwer, Dordrecht

Meylan A (1988) Spongivory in hawksbill turtles: a diet of glass. Science 239:393-395

* Mortimer JA, Donnelly M (2008) Eretmochelys imbricata. The IUCN Red List of Threatened Species 2008: e.T8005A12881238. http://dx.doi.org/10.2305/IUCN.UK. 2008.RLTS.T8005A12881238.en (accessed 16 May 2017)

Musick JA, Limpus CJ (1997) Habitat utilization and migration in juvenile sea turtles. In: Lutz PL, Musick JA (eds) The biology of sea turtles. CRC Press, Boca Raton, FL, p 137-164

O'Toole AC, Danylchuk AJ, Goldberg TL, Suski CD, Philipp DP, Brooks E, Cooke SJ (2011) Spatial ecology and residency patterns of adult great barracuda (Sphyraena barracuda) in coastal waters of The Bahamas. Mar Biol 158: 2227-2237

R Core Team (2017) R: a language and environment for statistical computing. R Foundation for Statistical Computing, Vienna

* Revelles M, Cardona L, Aguilar A, San Félix M, Fernández G (2007) Habitat use by immature loggerhead sea turtles in the Algerian Basin (western Mediterranean): swimming behaviour, seasonality and dispersal pattern. Mar Biol 151:1501-1515

* Scales KL, Lewis JA, Lewis JP, Castellanos D, Godley BJ, Graham RT (2011) Insights into habitat utilisation of the hawksbill turtle, Eretmochelys imbricata (Linnaeus, 1766), using acoustic telemetry. J Exp Mar Biol Ecol 407:122-129

Selby T, Hart K, Fujisaki I, Smith B and others (2016) Can you hear me now? Range-testing a submerged passive acoustic receiver array in a Caribbean coral reef habitat. Ecol Evol 6(14):4823-4835

* Simpfendorfer CA, Heupel MR, Hueter RE (2002) Estimation of short-term centers of activity from an array of omnidirectional hydrophones and its use in studying animal movements. Can J Fish Aquat Sci 59:23-32

Simpfendorfer CA, Huveneers C, Steckenreuter A, Tattersall K, Hoenner X, Harcourt R, Heupel MR (2015) Ghosts in the data: false detections in VEMCO pulse position modulation acoustic telemetry monitoring equipment. Anim Biotelem 3:1-10

Stergiou KI, Browman HI (eds) (2005) Politics and socioeconomics of ecosystem-based management of marine resources. Mar Ecol Prog Ser 300:241-296

* Strindberg S, Coleman RA, Burns Perez VR, Campbell CL, Majil I, Gibson J (2016) In-water assessments of sea turtles at Glover's Reef Atoll, Belize. Endang Species Res 31: 211-225

*van Dam RP, Diez CE (1997) Diving behaviour of immature hawksbills (Eretmochelys imbricata) in a Caribbean reef habitat. Coral Reefs 16:133-138 
van Dam RP, Diez CE (1998) Home range of immature hawksbill turtles (Eretmochelys imbricata (Linnaeus)) at two Caribbean islands. J Exp Mar Biol Ecol 220: $15-24$

Witt MJ, McGowan A, Blumenthal JM, Broderick AC and others (2010) Inferring vertical and horizontal movements of juvenile marine turtles from time-depth recorders. Aquat Biol 8:169-177

WWood LD, Brunnick B, Milton SL (2017) Home range and movement patterns of subadult hawksbill sea

Editorial responsibility: Brendan Godley, University of Exeter, Cornwall Campus, UK turtles in southeast Florida. J Herpetol 51:58-67

Worton BJ (1987) A review of models of home range for animal movement. Ecol Model 38:277-298

* Zeh DR, Heupel MR, Limpus CJ, Hamann M and others (2015) Is acoustic tracking appropriate for air-breathing marine animals? Dugongs as a case study. J Exp Mar Biol Ecol 464:1-10

* Zeller KA, McGarigal K, Whiteley AR (2012) Estimating landscape resistance to movement: a review. Landsc Ecol $27: 777-797$

Submitted: May 30, 2018; Accepted: July 17, 2019

Proofs received from author(s): September 18, 2019 